\title{
Betaling for ubenyttet time
}

\author{
Rådet for legeetikk får av og til klager vedrørende legens økonomiske krav. I slike saker hevdes det at leger \\ tar seg for godt betalt. For mange legetjenester finnes det fastsatte takster for hva leger kan kreve for sine \\ tjenester. Imidlertid er det fortsatt en god del helsetjenester der legen bestemmer prisen. Rådet for legeetikk \\ er opptatt av at leger skal vise nøkternhet i sine økonomiske krav.
}

Mange leger erfarer at pasienter uteblir fra avtalt time. Nylig behandlet Rådet for legeetikk en klage fra en pasient som ble fakturert for ubenyttet time som ifølge legen ikke var avbestilt i tide. Klager var innlagt på sykehus og fikk ikke meldt fra tidsnok.

Klager hadde time hos en spesialist en mandag. Hun ble akuttinnlagt på sykehus lørdagen før den avtalte timen, og ektefellen fikk ikke gitt beskjed om uteblivelsen før mandag morgen. Han forsøkte å kontakte legekontoret dagen etter innleggelsen, men legekontoret var stengt da og ingen beskjed kunne bli gitt. Pasienten ble avkrevd betaling via det firmaet som sendte ut fakturaer for legekontoret. Klager henvendte seg til legekontoret om det hun mente var et urimelig økonomisk krav fra legen, men fikk beskjed om at klagen måtte rettes til faktureringsfirmaet.

\section{Rådets behandling}

Rådet for legeetikk vurderte klagen i forhold til Etiske regler for leger kapittel I $\S \S 2$ og 8. Kapittel I $\S 2$, første ledd: «Legen skal ivareta den enkelte pasients interesse og integritet. Pasienten skal behandles med omsorg og respekt.» Kapittel I § 8: «En lege skal i sin virksomhet ta hensyn til pasientens økonomi og ikke beregne seg urimelige honorarer.»

I sin uttalelse i saken henviste rådet til normaltariffen, der det står (merknad B2): «For bestilt time som ikke benyttes, dvs. at pasienten uteblir uten varsel eller avbestiller senere enn 24 timer før avtalt tid, kan pasienten avkreves konsultasjonshonorar». Det står altså 24 timer og ikke 24 timer/ arbeidsdagen før.

Rådet var klar på at formuleringen «kan» i forskriftens merknad B2 oppfordrer til å bruke skjønn. Rådet var på generelt grunn-

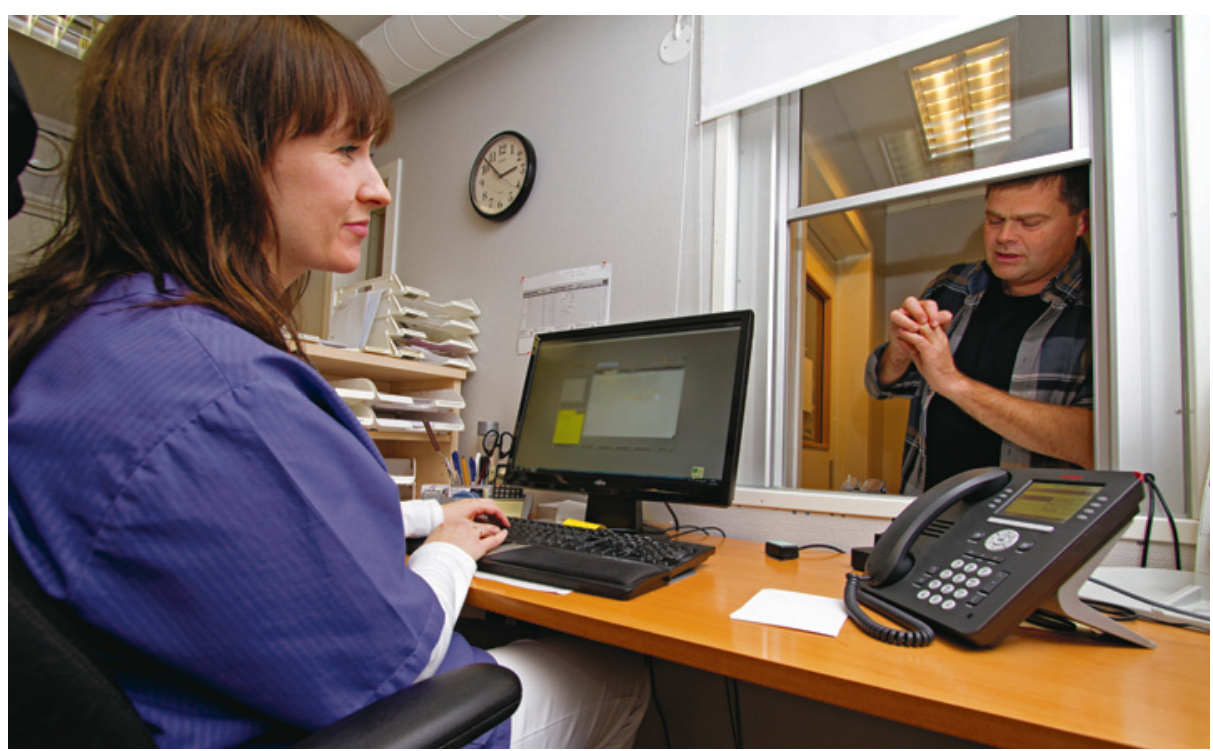

Illustrasjonsfoto: Ole Kristian Losvik

lag enig $i$ at uteblivelse fra time representerer så vel misbruk av ressurser som økonomisk tap for legen og at det ikke er urimelig at legen søker å dekke inn noe av sitt inntektstap. Det må imidlertid brukes skjønn. I denne saken fant rådet at det var rimelig å frafalle kravet. Rådet pekte videre på at selv om leger har satt bort fakturering til et firma, har leger et selvstendig ansvar for at fakturakrav er rimelige og for å kommunisere respektfullt med pasienter som eventuelt klager. Rådet mente følgelig at det var feil å avvise pasientens klage og henvise klager til faktureringsselskapet. Legen fikk derfor kritikk for å ha brutt de etiske reglers krav om å ivareta pasientens interesse og integritet, jf. kapittel I $§ 2$ samt kapittel I $\S 8$ om å ivareta pasientens økonomi og ikke beregne seg urimelige honorarer.
I sin uttalelse ga rådet legen kritikk og uttrykte en forventning om at fremtidig faktureringspraksis ble endret i tråd med kritikken.

\section{Svein Aarseth \\ svein.aarseth@legeforeningen.no \\ Rådet for legeetikk \\ Den norske legeforening}

Svein Aarseth (f. 1950) er fastlege på Frysja legekontor og leder i Rådet for legeetikk. Forfatter har fylt ut ICMJE-skjemaet og oppgir ingen interessekonflikter.

Mottatt 8.1. 2015 og godkjent 15.2. 2015. Redaktør: Siri Lunde Strømme.

\section{Saker behandlet av Rådet for legeetikk publiseres i årsmeldingene på nettsiden www.legeforeningen.no/etikk}

